\title{
Anticancer Activity and Apoptosis Induction of Gold(III) Complexes Containing 2,2'-Bipyridine-3,3'-dicarboxylic Acid and Dithiocarbamates
}

\author{
Ali Alhoshani ${ }^{1, * D}$, Adam A. A. Sulaiman ${ }^{2}{ }^{D}$, Homood M. As Sobeai ${ }^{1}$, Wajhul Qamar ${ }^{1}$, Moureq Alotaibi ${ }^{1}$, \\ Khalid Alhazzani ${ }^{1}$, Muhammad Monim-ul-Mehboob ${ }^{3}$, Saeed Ahmad ${ }^{4}$ and Anvarhusein A. Isab ${ }^{2, *}$
}

1 Department of Pharmacology and Toxicology, College of Pharmacy, King Saud University, P.O. Box 2457, Riyadh 11451, Saudi Arabia; hassobeai@KSU.EDU.SA (H.M.A.S.); wqidris@KSU.EDU.SA (W.Q.); mralotaibi@KSU.EDU.SA (M.A.); Kalhazzani@ksu.edu.sa (K.A.)

2 Department of Chemistry, King Fahd University of Petroleum and Minerals, Dhahran 31261, Saudi Arabia; adamahmed@kfupm.edu.sa

3 Department of Chemistry, Government College of Science, Wahdat Road, Lahore, Pakistan; mmmehboob786@hotmail.com

4 Department of Chemistry, College of Sciences and Humanities, Prince Sattam bin Abdulaziz University, Al-Kharj 11942, Saudi Arabia; saeed_a786@hotmail.com

* Correspondence: ahoshani@ksu.edu.sa (A.A.); aisab@kfupm.edu.sa (A.A.I.)

Citation: Alhoshani, A.; Sulaiman, A.A.A.; Sobeai, H.M.A.; Qamar, W.; Alotaibi, M.; Alhazzani, K.

Monim-ul-Mehboob, M.; Ahmad, S.; Isab, A.A. Anticancer Activity and Apoptosis Induction of Gold(III) Complexes Containing 2,2'-Bipyridine-3,3'-dicarboxylic Acid and Dithiocarbamates. Molecules 2021 26, 3973. https://doi.org/10.3390/

molecules 26133973

Academic Editor: Mauro Ravera

Received: 22 May 2021

Accepted: 23 June 2021

Published: 29 June 2021

Publisher's Note: MDPI stays neutral with regard to jurisdictional claims in published maps and institutional affiliations.

Copyright: (c) 2021 by the authors. Licensee MDPI, Basel, Switzerland. This article is an open access article distributed under the terms and conditions of the Creative Commons Attribution (CC BY) license (https:// creativecommons.org/licenses/by/ $4.0 /)$.
Abstract: Three novel gold(III) complexes (1-3) of general composition $\left[\mathrm{Au}(\mathrm{Bipydc})\left(\mathrm{S}_{2} \mathrm{CNR}_{2}\right)\right] \mathrm{Cl}_{2}$ (Bipydc $=2,2^{\prime}$-bipyridine-3,3'-dicarboxylic acid and $\mathrm{R}=$ methyl for dimethyldithiocarbamate (DMDTC), ethyl for diethyldithiocarbamate (DEDTC), and benzyl for dibenzyldithiocarbamate (DBDTC)) have been synthesized and characterized by elemental analysis, FTIR and NMR spectroscopic techniques. The spectral results confirmed the presence of both the Bipydc and dithiocarbamate ligands in the complexes. The in vitro cytotoxic studies demonstrated that compounds $1-3$ were highly cytotoxic to A549, HeLa, MDA-231, and MCF-7 cancer cells with activities much higher (about 25-fold) than cisplatin. In order to know the possible mode of cell death complex 2, [Au(Bipydc)(DEDTC)]Cl $\mathrm{C}_{2}$ was further tested for induction of apoptosis towards the MCF-7 cells. The results indicated that complex 2 induces cell death through apoptosis.

Keywords: gold(III); 2,2'-bipyridine-3,3'-dicarboxylic acid; anti-cancer activity; dithiocarbamates; apoptosis

\section{Introduction}

The clinical success of platinum anti-cancer drugs [1-4] prompted a great deal of attention towards the development of isoelectronic gold(III) anti-cancer complexes with the anticipation that they might have activity similar to that of platinum(II) anti-tumor drugs [5-17]. Both gold(III) and platinum(II) give rise to square planar geometries; but the high redox potential for gold(III) compounds, their relatively poor stability, and faster ligand substitution reactions could impede their application as medicinal agents under normal physiological conditions $[5-14,17,18]$. However, the coordination of bidentate and polydentate ligands, such as 2,2'-bipyridine and terpyridine, provides sufficient stabilization to gold(III) compounds under physiological conditions and shows favorable anti-tumor properties $[7,8,11-16]$.

As a result, assorted sets of a potential anti-tumor gold(III) compounds were synthesized and characterized, which exhibited significant anti-proliferative effects in vitro under similar physiological conditions. They include the gold(III) complexes of bipyridines [11-13,19-23], diamines [16,17,23-29], quinolones [16], dithiocarbamates [30-37], and porphyrinates [38,39], as well as dinuclear gold(III) complexes $[13,22,23]$ and a variety of organogold(III) compounds [37,40-42]. 
Mechanistic studies on the cytotoxic gold(III) complexes indicate that these complexes show a weak binding affinity to DNA, suggesting that they exert anti-proliferative effects, mainly through DNA-independent mechanisms [7,11-13,43]. The compounds of gold(III) have shown high reactivity to various protein models indicating that the interactions between gold and proteins are responsible for their cytotoxic effects $[7,13,23,33,44-47]$. The apoptosis for such compounds can be caused by direct mitochondrial damage [42,48]. The key targets for these gold compounds are some unusual proteins, for example mitochondrial selenoprotein, thioredoxin reductase, the proteasome and the nuclear factor kb (NF-kb) [32,33,47-50]. The strong inhibition of thioredoxin reductase could ultimately lead to the profound change of the mitochondrial membrane potential, to cause cytochrome $c$ release and subsequent excitation of apoptosis [49].

Gold(III) complexes containing bipyridine ligands have been extensively investigated for the cytotoxic properties by Messori and other groups [11-13,22,23]. These complexes exist in mononuclear [13] as well as dinuclear forms [22]. The gold(III) atom in [Au(bipy) $\mathrm{X}_{2}$ ] + complexes has a square-planar geometry, attained by two $\mathrm{N}$ atoms from the bipyridine and two halide/pseudohalide ions. Angela Casini and co-workers have reported the synthesis and anti-cancer properties of the gold(III) series of compounds containing bipyridine derivatives. They noted that the compound with methylated bipyridine showed more cytotoxic activity against A2780 (the human ovarian carcinoma cell line) in comparison with methoxylated, aminated, and even no-branched derivatives [13]. Amani et al. elaborated on the study by using different anions for the cationic gold(III) bipyridine derivative [21] Counter anions have been shown to play a major role in the cytotoxicity of the related compounds in various cell lines. The complexes with the relevant anionic part of $\left[\mathrm{AuX}_{4}\right]^{-}$ $(\mathrm{X}=\mathrm{Cl}$ and $\mathrm{Br})$ displayed good agreement in their anti-cancer activities toward human cancer cell lines.

Due to their strong cell growth-inhibitory effects, gold(III)-dithiocarbamates have received significant attention as potential drugs for cancer treatment [30-37]. In this context, we have taken advantage of the idea of linking the well-known gold(III)-based bipyridine moiety with the effective chemo-protective function of dithiocarbamates, which proved to be an efficient strategy $[19,20]$. In an effort to develop more effective anticancer agents with reduced toxicity, we report here the synthesis, spectral characterization, in vitro anti-tumor activities, DNA damage, and cell death studies of three new gold(III) compounds (1-3) using 2,2'-bipyeidine-3,3'-dicarboxylic acid ligand (Bipydc) along with three dithiocarbamates. The possible structures of the investigated complexes are shown in Scheme 1. 

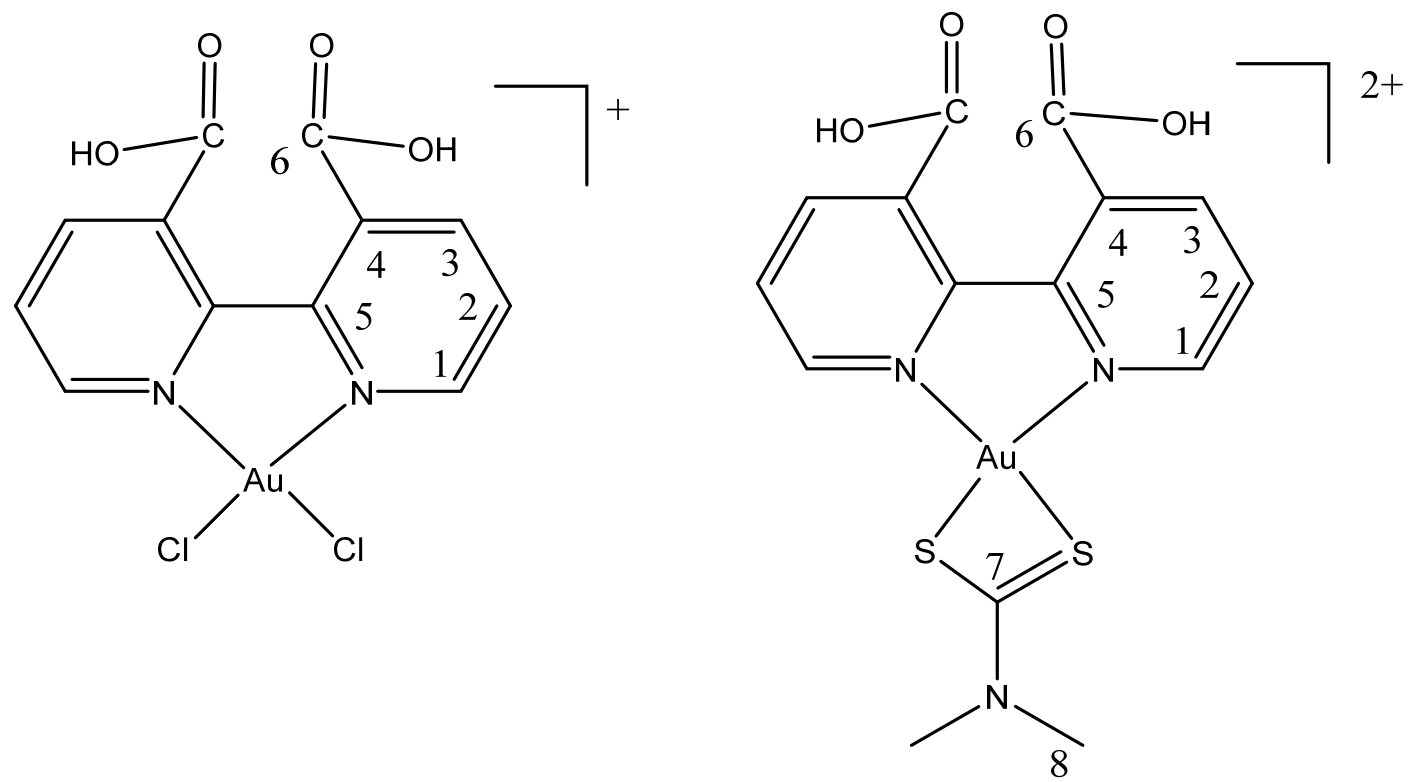

A

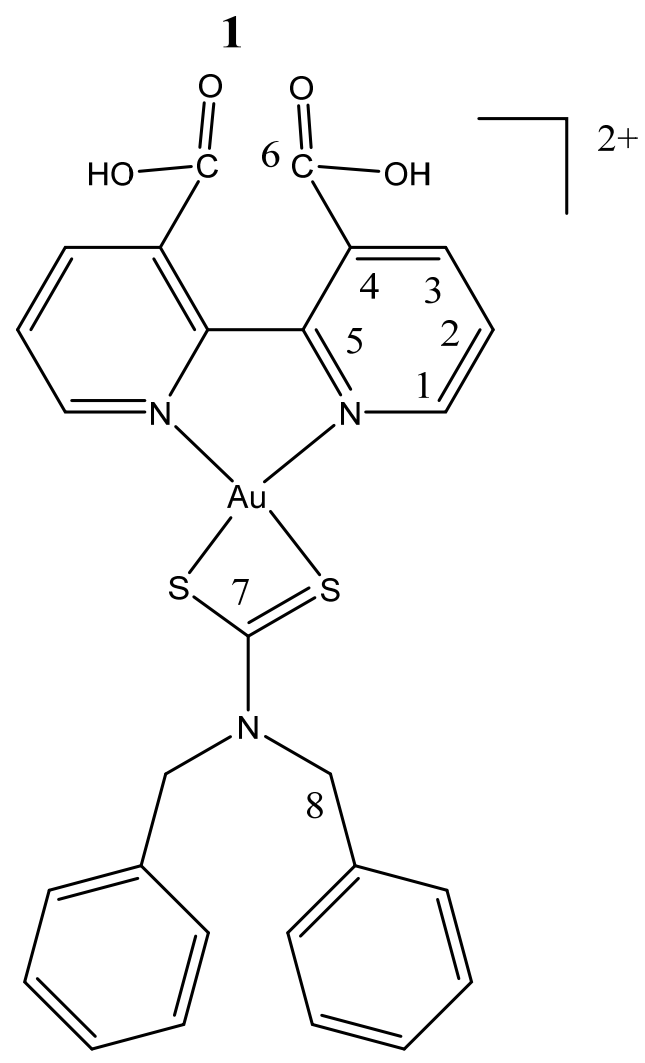

3

Scheme 1. The possible structures of gold(III) complexes along with resonance assignment. In all cases, counter ions are chloride.

\section{Results and Discussion}

\subsection{Synthesis and Spectroscopic Characterization}

The complexes were prepared by treating $\mathrm{Na}\left[\mathrm{AuCl}_{4}\right] \cdot 2 \mathrm{H}_{2} \mathrm{O}, 2,2^{\prime}$-bipyridine-3,3'dicarboxylic acid, and sodium salts of dithiocarbamates in 1:1:1 stoichiometric ratio in ethanol. The complexes were isolated as dry powder solids, soluble in DMSO and chloroform. The stoichiometry of complexes 1-3 was formulated on the basis of elemental analysis. The complexes 1-3 are assumed to be a classic mononuclear species with square- 
planar geometry [31-33,37]. In all cases the gold(III) center is stabilized by the presence of two nitrogen ligands, and coordination of dithiocarbamates takes place through the sulfur-donating atoms of the NCSS moiety in a bidentate symmetrical mode.

Due to the steric effects of the substituents placed at the 3,3'-positions, the two pyridine rings of the bipyridyl ligand (Bipydc) in the complexes are not coplanar [51]. The structure of the platinum(II) complex [Pt(Bipydc) $\left.\mathrm{Cl}_{2}\right] \cdot 2 \mathrm{DMF}$ shows that Bipydc is coordinated to platinum through its nitrogen atoms. However, the coordinated pyridine rings are twisted by $26.5^{\circ}$, relative to one another, owing to the steric repulsion between the carboxylic acid groups in the 3,3'-positions of Bipydc [52]. A similar structural arrangement is predicted for the present series of the complexes. In some cases, coordination through carboxyl groups is also observed. For example, in a recent report on copper(II) coordination polymer with 2,2'-bipyridyl-3,3'-dicarboxylic acid $\left\{\left[\mathrm{Cu}(\mathrm{Bipydc})\left(\mathrm{H}_{2} \mathrm{O}\right)\right] \cdot 2 \mathrm{H}_{2} \mathrm{O}\right\}_{n}$, the ligand is found to coordinate through both the nitrogen and oxygen atoms of the carboxyl group, but to different metal ions [53].

The selected IR frequencies of the ligands and their gold(III) complexes are given in Table 1. In the IR spectra of the complexes (1-3), a strong band around $1500 \mathrm{~cm}^{-1}$

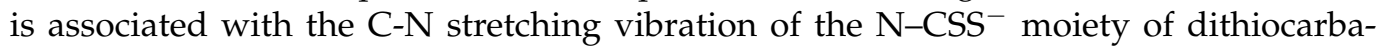
mates [30-32,37,54]. This value defines a carbon-nitrogen bond order intermediate between a single bond $\left(v=1350-1250 \mathrm{~cm}^{-1}\right)$ and a double bond $\left(v=1690-1640 \mathrm{~cm}^{-1}\right)$ [54]. The $\mathrm{C}=\mathrm{N}$ stretching mode of the bipyridine ligand also falls in the same region $[13,21]$ and is therefore indistinguishable from this band. The higher-frequency shifts in $v(\mathrm{~N}-\mathrm{CSS})$ mode of dithiocarbamates upon coordination are consistent with an increase in the $\mathrm{C}-\mathrm{N}$ double bond character and support the bidentate coordination of the S atoms of (-CSS) moieties to the metal center. The bands in the region of the $1100-900 \mathrm{~cm}^{-1}$ represent the symmetrical and asymmetrical vibrational modes of (CSS) and (CSS) stretching, respectively. The C-H (aromatic) and C-H (aliphatic) stretching vibrations appear around 3000 and $2900 \mathrm{~cm}^{-1}$, respectively. In addition, the signal at about $3400 \mathrm{~cm}^{-1}$ represents the $\mathrm{O}-\mathrm{H}$ absorptions of the $\mathrm{COOH}$ groups of Bipydc ligands. The appearance of this band indicates that the carboxylate ions are not involved in complexation. The presence of the absorption band characteristics of Bipydc and dithiocarbamates suggests the coordination of both ligands to the gold(III) center.

Table 1. IR frequencies $\left(\mathrm{cm}^{-1}\right)$ of free ligands and their complexes.

\begin{tabular}{ccccccc}
\hline Ligand/Complex & $\boldsymbol{v}(\mathbf{O}-\mathrm{H})$ & $\boldsymbol{v}(\mathbf{C}-\mathrm{H})$ & $\boldsymbol{v}(\mathbf{C O O})$ & $\boldsymbol{v}(\mathbf{N}-\mathrm{CS})$ & $\boldsymbol{v}(\mathbf{C}=\mathrm{C})$ & $\boldsymbol{v}(\mathrm{CSS})$ \\
\hline DMDTC & - & - & - & 1488 & - & 926 \\
DEDTC & - & - & - & 1445 & - & 986 \\
DBDTC & - & 2923,2854 & 1600 & 1467 & 1436 & 985 \\
$\mathbf{A}$ & 3451 & 2953,2851 & 1645 & - & - & - \\
$\mathbf{1}$ & 3448 & - & 1652 & 1575 & 1399 & 1047,967 \\
$\mathbf{2}$ & 3440 & 2975,2853 & 1662 & 1550 & 1347 & 1065,993 \\
$\mathbf{3}$ & 3439 & 2928,2854 & 1716 & 1549 & 1435 & 1067,904 \\
\hline
\end{tabular}

The ${ }^{1} \mathrm{H}$ and ${ }^{13} \mathrm{C}$-NMR chemical shifts of the complexes are provided in Tables 2 and 3 , respectively. In the ${ }^{1} \mathrm{H}$ NMR spectra of complexes $\mathbf{1}$ and $\mathbf{2}$, the $\mathrm{N}(\mathrm{CH})$ protons of dithiocarbamates were detected between 3 and $4 \mathrm{ppm}$ and around $5 \mathrm{ppm}$ for 3 . The splitting pattern of the protons attached to the R groups is usual. The ${ }^{1} \mathrm{H}$ NMR spectrum of complex 3 shows multiple peaks centered between $\delta 7.22$ and $7.33 \mathrm{ppm}$, due to the protons of the benzene ring. The aromatic protons of bipyridine resonate around $7 \mathrm{ppm}$. The $\mathrm{N}=\mathrm{C}-\mathrm{H}$ proton appeared at the most downfield position of about $8.8 \mathrm{ppm}$. 
Table 2. ${ }^{1} \mathrm{H}-\mathrm{NMR}$ chemical shifts for free ligands and their compounds in DMSO- $d_{6}$.

\begin{tabular}{|c|c|c|c|c|c|c|c|}
\hline Ligand/Complex & H-1 & H-2 & H-3 & H-6 & H-8 & H-9 & Aromatic-Hs \\
\hline DMDTC & - & - & - & - & $3.35 \mathrm{~s}$ & - & - \\
\hline DEDTC & - & - & - & - & $3.93 \mathrm{q}$ & $1.13 \mathrm{t}$ & - \\
\hline DBDTC & - & - & - & - & $5.31,4.77 \mathrm{~d}$ & - & $\begin{array}{c}7.24 \mathrm{~m}-7.39 \\
\mathrm{~m}\end{array}$ \\
\hline A & $8.71 \mathrm{~d}$ & $7.58 \mathrm{t}$ & $8.31 \mathrm{~d}$ & - & - & - & - \\
\hline 1 & $8.67 d$ & $7.52 \mathrm{t}$ & $8.26 \mathrm{~d}$ & - & $3.36 \mathrm{~s}$ & - & - \\
\hline 2 & $8.69 \mathrm{~d}$ & $7.56 \mathrm{t}$ & $8.29 \mathrm{~d}$ & - & $3.76 \mathrm{q}$ & $1.28 \mathrm{t}$ & - \\
\hline 3 & $8.89 \mathrm{~d}$ & $7.77 \mathrm{t}$ & $8.78 \mathrm{~d}$ & 10.13 & $4.85,4.76 \mathrm{~d}$ & - & $\begin{array}{c}7.22 \mathrm{~m}-7.33 \\
\mathrm{~m}\end{array}$ \\
\hline
\end{tabular}

s: Singlet; d: Doublet, t: Triplet; q: Quartet; m: Multiplet.

Table $3 .{ }^{13} \mathrm{C}-\mathrm{NMR}$ chemical shifts for free ligands and their complexes in DMSO- $d_{6}$.

\begin{tabular}{ccccccccccc}
\hline Ligand/Complex & C1 & C2 & C3 & C4 & C5 & C6 & C = S & C8 & C9 & Aromatic Cs \\
\hline DMDTC & - & - & - & - & - & - & 208.3 & 45.7 & - & - \\
DEDTC & - & - & - & - & - & - & 206.4 & 49.5 & 12.1 & - \\
DBDTC & - & - & - & - & - & - & 213.1 & 56.9 & - & $127.7-137.2$ \\
A & 157.9 & 126.8 & 138.4 & 123.3 & 150.3 & 166.7 & - & - & - & - \\
$\mathbf{1}$ & 158.8 & 126.6 & 137.8 & 122.8 & 150.6 & 167 & 193.9 & 40.3 & - & - \\
$\mathbf{2}$ & 158.2 & 126.6 & 138.1 & 123 & 150.3 & 166.7 & 193.8 & 46.5 & 12 & - \\
$\mathbf{3}$ & 155.9 & 119.4 & 142.8 & 122.8 & 151.2 & & 193.4 & 52.1 & - & \\
\hline
\end{tabular}

The ${ }^{13} \mathrm{C}\left\{{ }^{1} \mathrm{H}\right\}$ NMR spectra of the complexes exhibit signals due to the N-CH and CS2 carbons of dithiocarbamates near 50 and 200 ppm, respectively. A significant upfield shift in the CS2 resonance is attributed to the lowering of the $\mathrm{C}=\mathrm{S}$ bond order upon coordination and a shift of N-C electron density, producing a partial double bond character in the $\mathrm{C}-\mathrm{N}$ bond. The aromatic carbons of the bipyridine ring resonate between 120 and 160 ppm. Downfield shifts in $\mathrm{C}=\mathrm{N}$ resonance of the ligands upon complexation indicates the binding of Bipydc to gold(III) through the imine nitrogen atom. The peaks due to carboxylate carbons are observed near $167 \mathrm{ppm}$. The ${ }^{1} \mathrm{H}$ and ${ }^{13} \mathrm{C}-\mathrm{NMR}$ chemical shift values are in accordance with the literature reports $[13,20,21,30,54]$.

\subsection{Cytotoxic Activity}

The in vitro cytotoxicity of synthesized gold(III) complexes (A, 1-3) was evaluated via MTT assays towards four cell lines: A549, HeLa, MDA-231, and MCF-7. The MTT signal is mainly influenced by the cellular metabolic activity, where higher metabolic activity of the cells will produce higher MTT signals, and vice versa. For comparison, the anti-cancer activity of cisplatin was also examined under the same conditions. The corresponding $\mathrm{IC}_{50}$ values are given in Table 4 . Comparisons of cell viability percentages for all cell lines are shown in Figures 1-4. All four complexes (A,1-3) displayed excellent cytotoxic activity, as compared to cisplatin. In most cases, the $\mathrm{IC}_{50}$ value of the complexes (1-3) was about $3 \mu \mathrm{M}$, while for cisplatin it was around $9 \mu \mathrm{M}$ (except for MCF-7, $31 \mu \mathrm{M}$ ). The cytotoxic effects of the complexes are comparable to each other against the selected four cells. It has been observed that the activity is enhanced upon the complexation of dithiocarbamates. Complex 1 was found to be the most effective against HeLa cells, 2 against MCF-7, and 3 against A549 cells. Figure 4 showed that complex 1 unexpectedly produced higher MTT signals at higher concentrations $(10,30$, and $100 \mu \mathrm{M})$ compared to lower concentrations $(3 \mu \mathrm{M})$ in MDA-231 cells. A possible explanation for the disparity of MTT signals between higher and lower concentrations is that at higher concentration complex 1 might have induced oxidative burst, which subsequently increased the metabolic activity of MDA cells, leading to the magnification of MTT signals despite the overall cellular death. The higher cytotoxicity of the complexes may be related to the strong binding of dithiocarbamate ligands with the gold(III) ion, which would increase its stabilization. Since cancer cells 
have a higher proliferative capacity than normal cells, the complexes are expected to target tumor cells via the induction of reactive oxygen species leading to DNA damage and cellular death $[55,56]$. The comparable cytotoxicity of the complexes reflects that the structure of dithiocarbamate has little influence on the anti-tumor properties of the complexes. Although the anti-tumor activities of complexes 1-3 are significant, they seem poor compared to those reported earlier for such complexes [20]. Further in vivo studies using mice models should be carried out to evaluate the safety of major organs and the efficacy of anti-cancer properties. Since these complexes bear structural similarities to cisplatin, it is proposed to use cisplatin as a positive control for dosing and comparison.

Table 4. $\mathrm{IC}_{50}$ values $(\mu \mathrm{M})$ of cisplatin and gold(III) compounds (A, 1-3) against A549, HeLa, MDA231, and MCF-7 cancer cell lines.

\begin{tabular}{ccccc}
\hline \multicolumn{5}{c}{ IC50 in $\mu \mathbf{M}$} \\
\hline Cisplatin & $9.61( \pm 0.08)$ & $9.3( \pm 0.2)$ & $7.8( \pm 0.02)$ & $31.06( \pm 0.1)$ \\
\hline $\mathbf{A}$ & $7.4( \pm 0.07)$ & $7.3( \pm 0.03)$ & $5.5( \pm 0.02)$ & $15.9( \pm 0.021)$ \\
\hline $\mathbf{1}$ & $3.02( \pm 0.1)$ & $2.8( \pm 0.05)$ & $3.3( \pm 0.01)$ & $4.08( \pm 0.019)$ \\
\hline $\mathbf{2}$ & $3.08( \pm 0.06)$ & $3.1( \pm 0.1)$ & $3.3( \pm 0.01)$ & $2.7( \pm 0.1)$ \\
\hline $\mathbf{3}$ & $3.1( \pm 0.5)$ & $3.7( \pm 0.07)$ & $4.1( \pm 0.03)$ & $3.7( \pm 0.019)$ \\
\hline
\end{tabular}

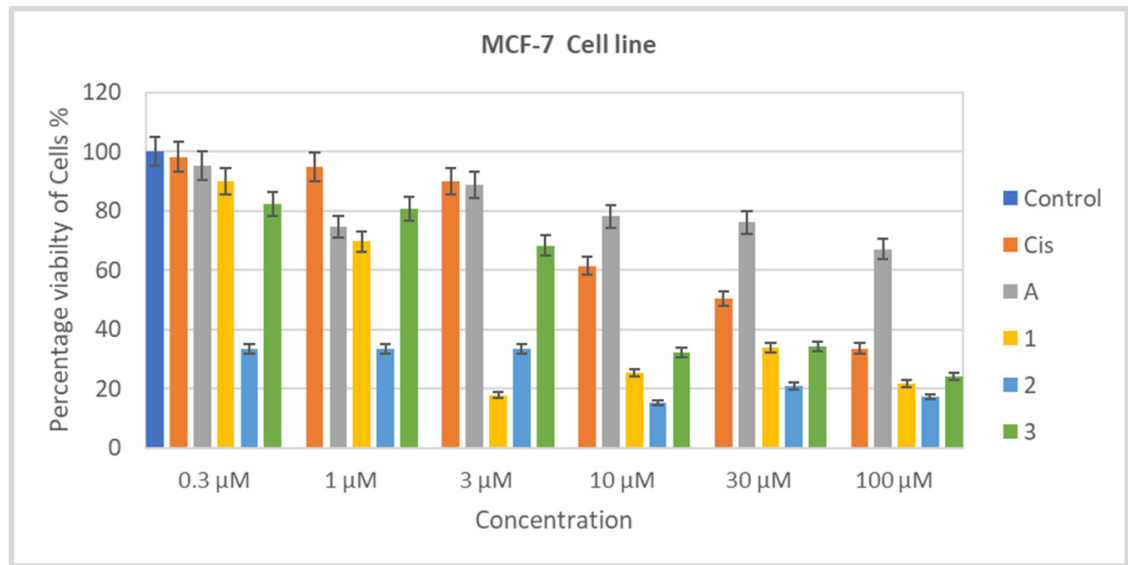

Figure 1. Effect of the concentration of complexes A, 1-3 and cisplatin on the viability of MCF-7 cells.

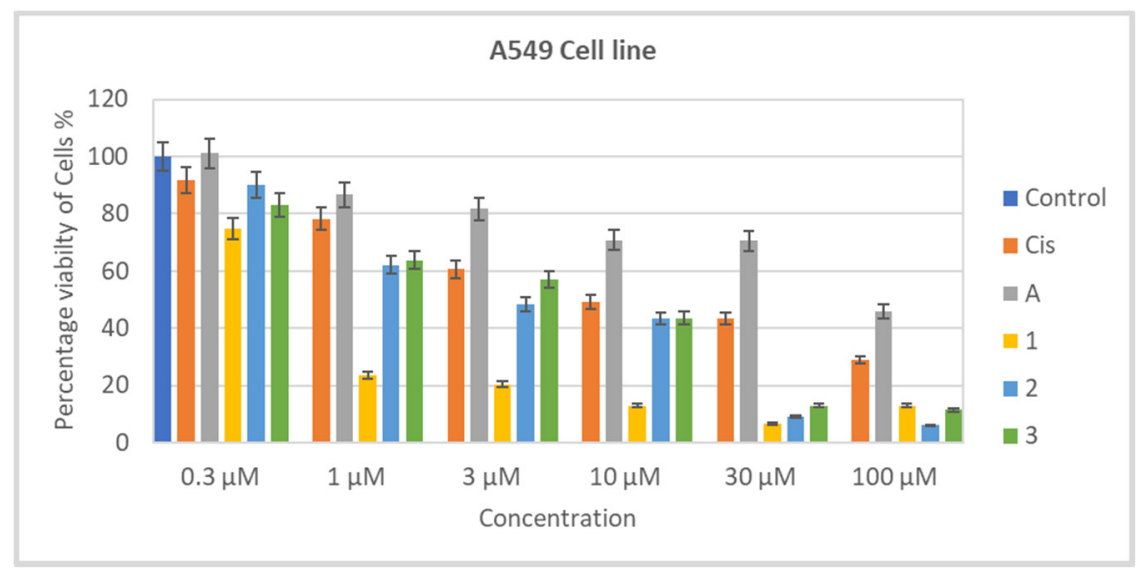

Figure 2. Effect of the concentration of complexes A, 1-3 and cisplatin on the viability of A549 cells. 


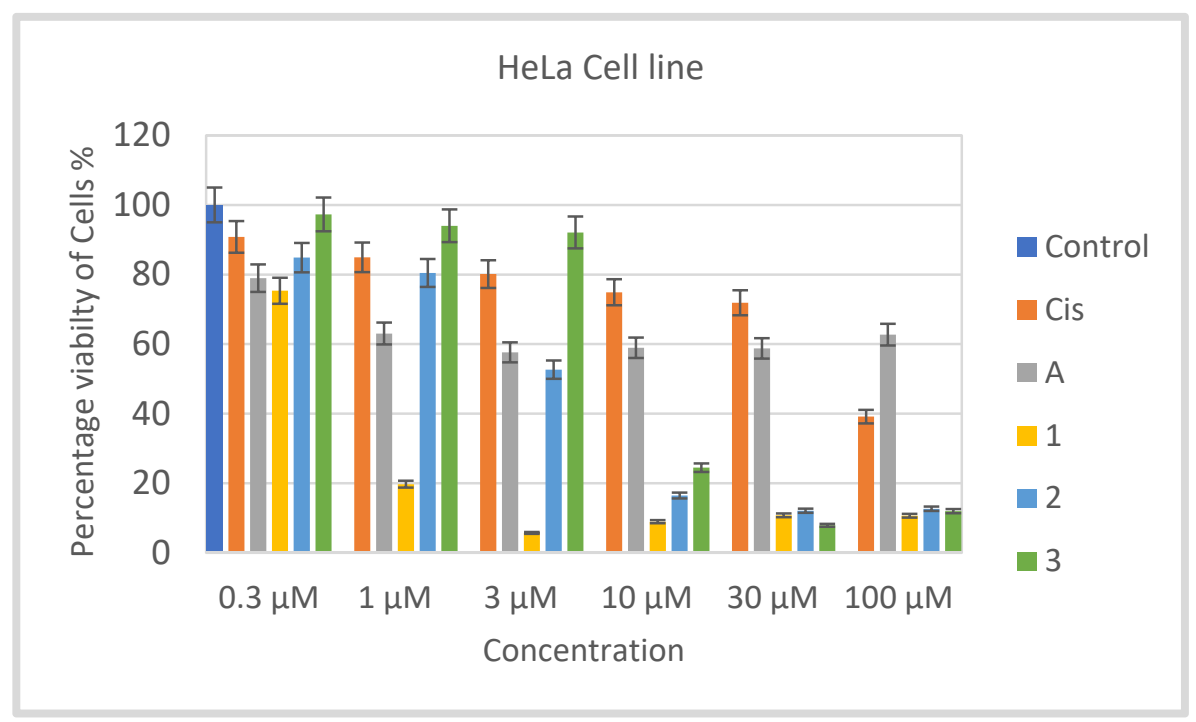

Figure 3. Effect of the concentration of complexes A, 1-3 and cisplatin on the viability of HeLa cells.

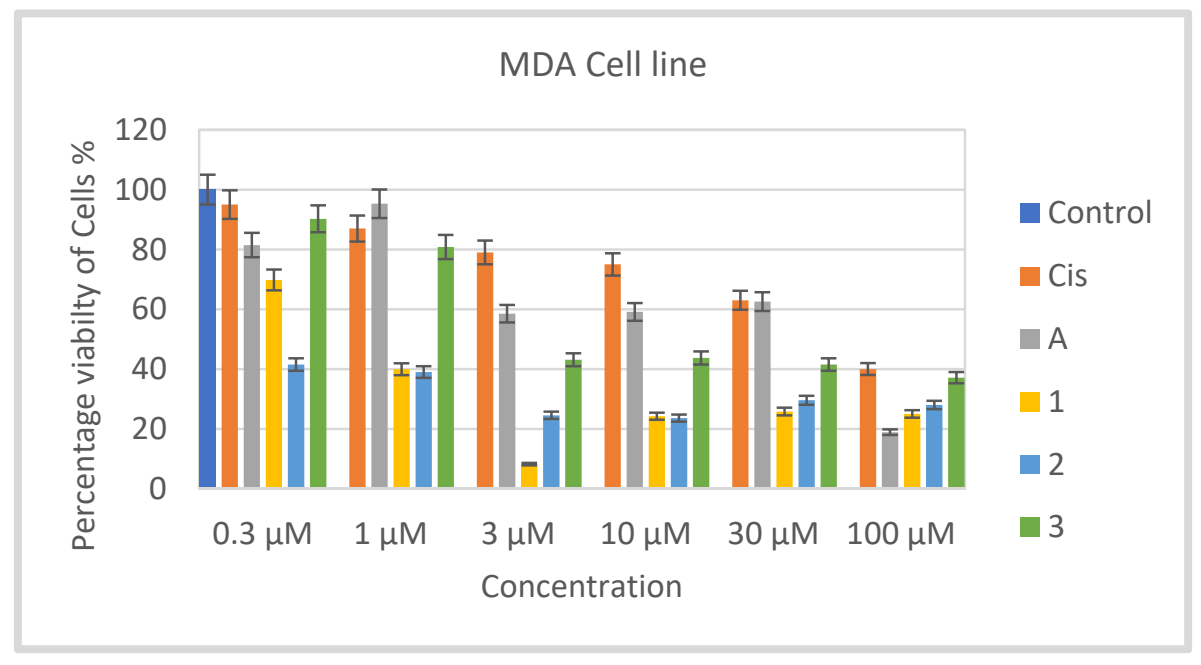

Figure 4. Effect of the concentration of complexes A, 1-3 and cisplatin on the viability of MDA cells.

\subsection{Apoptosis Induction}

To further investigate how the complexes inhibited proliferation, the induction of apoptosis for complex 2 was evaluated in MCF-7 cells after $24 \mathrm{~h}$. The control, $1 \mu \mathrm{M}$, and $5 \mu \mathrm{M}$ concentrations of the complex were used. The observed apoptotic effect was compared to the control and expressed in Figure 5. The results showed that complex 2 inhibited apoptosis proliferation. Distinct morphological characteristics, including cytoplasmic and nuclear condensation, breakdown in DNA, mucosal dysfunction, and microvilli, are usually associated with apoptosis. The exposure of phosphatidylserine (PS) is usually before plasma membrane integrity loss during apoptosis. Healthy cells do not react to annexin $\mathrm{V}$, a marker of PS, while apoptosis-prone cells are reactive to annexin V [57]. Figure 5 shows the percentage of apoptotic cells (MCF-7) increased in a dose-dependent manner. The total percentage rates of early apoptosis and late apoptosis for MCF7 were $1.68 \pm 0.33 \%$, $56.78 \pm 1.50 \%$, and $70.07 \pm 0.42 \%$, respectively. It is clear that complex 2 induced apoptosis at a sub-toxic dose. 

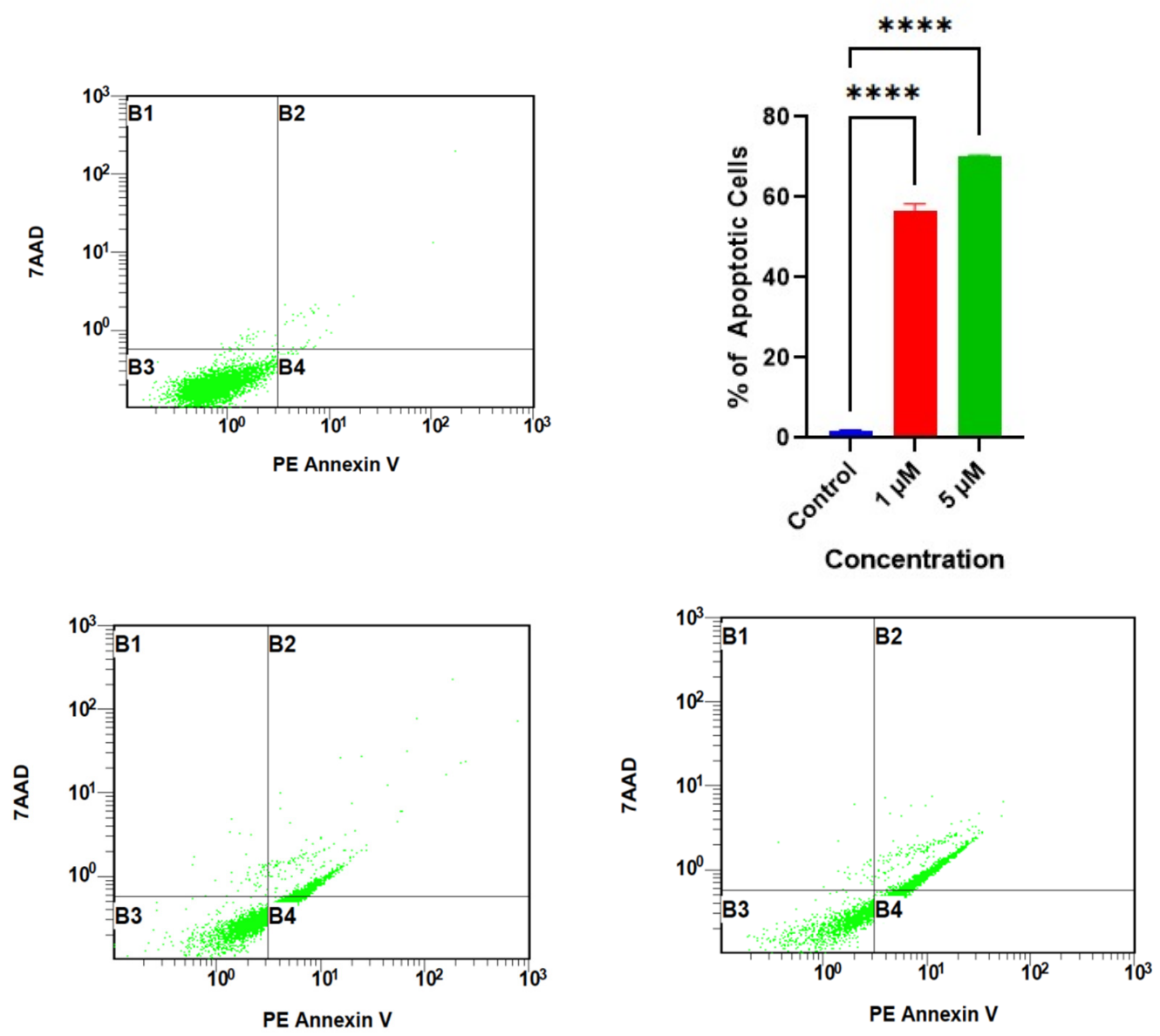

Figure 5. Apoptotic evaluation by Annexin V staining of MCF-7 cells treated with 2 . The $\left.{ }^{* * * *}\right)$ is significant compare to control.

\subsection{DNA Damage}

Conventional anti-cancer agents are genotoxic. They induce DNA damage, crumble the cancer cell's ability to proliferate, and force cells to undergo apoptosis. To assess whether complex 2 behaved in a manner similar to classic genotoxic chemotherapy drugs and that DNA damage was the underlying mechanism for the elevation of apoptosis, the total DNA damage of MCF7 cells was measured $24 \mathrm{~h}$ after treatment. Two treatment concentrations of complex solutions $1 \mu \mathrm{M}$ and $5 \mu \mathrm{M}$ were compared to control cells that were left with no treatment. The assay revealed significantly increased chromosomal DNA strand breaks upon addition of the complex in dose-dependent manner. The total DNA damage percentages of $1 \mu \mathrm{M}$ and $5 \mu \mathrm{M}$ treated apoptotic cells were $8 \%$ and $27 \%$, respectively, compared to the control cells, which was 5\% (Figure 6). These data suggest that complex 2 induced DNA insults in the treated cells leading to promote apoptosis.

\subsection{Stability of Complexes $\mathbf{1}$ and $\mathbf{3}$}

The stability of complexes $\mathbf{1}$ and $\mathbf{3}$ was checked in acetonitrile with $0.5 \% v / v$ PBS ( $\mathrm{pH}$ 7.0) at room temperature using UV-visible spectroscopy. The complexes are completely soluble in both acetonitrile and phosphate buffer solution (PBS, pH 7.0). The spectra were taken in the beginning and after $24 \mathrm{~h}$ and $72 \mathrm{~h}$, as shown in Figure 7 . No changes were observed in the spectra, indicating their stability in solution. 
A

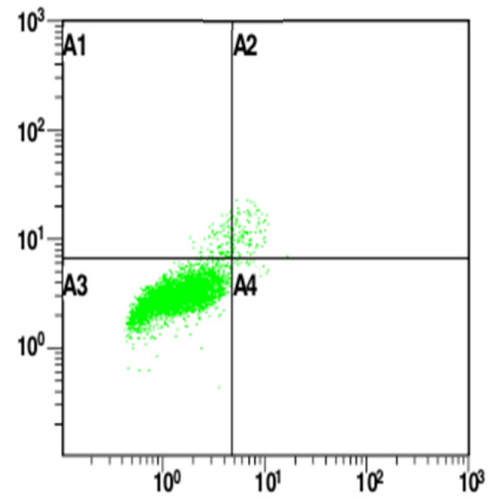

C

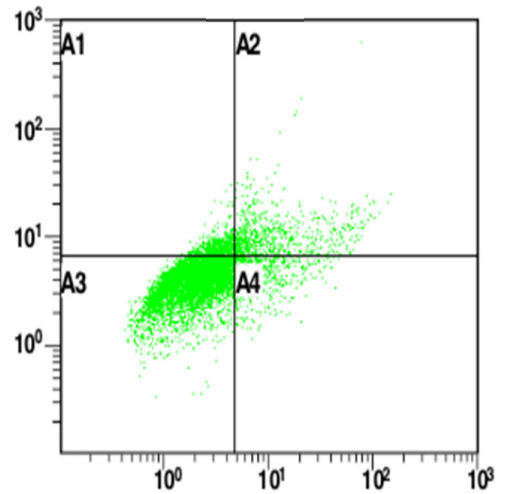

B

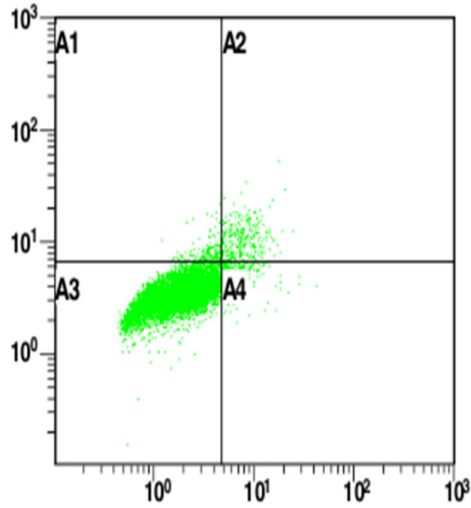

D

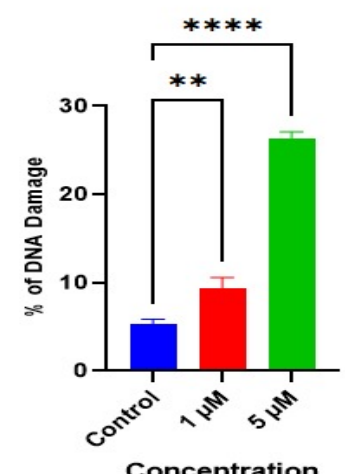

Figure 6. DNA damage-inducing effect of complex 2. In (A-C), A1: percentage of ATM-activated cells, A2: percentage of DNA double-strand breaks (dual activation of both ATM and H2A.X), A3: percentage of negative cells (e.g., no DNA damage), (D) the total DNA damage (A1 + A2 + A4). A significant increase in DNA strand breaks was observed in complex 2 treated cells in a dose-dependent manner. The $\left.{ }^{* *}\right)$ and ${ }^{(* * *)}$ is significant compare to control.

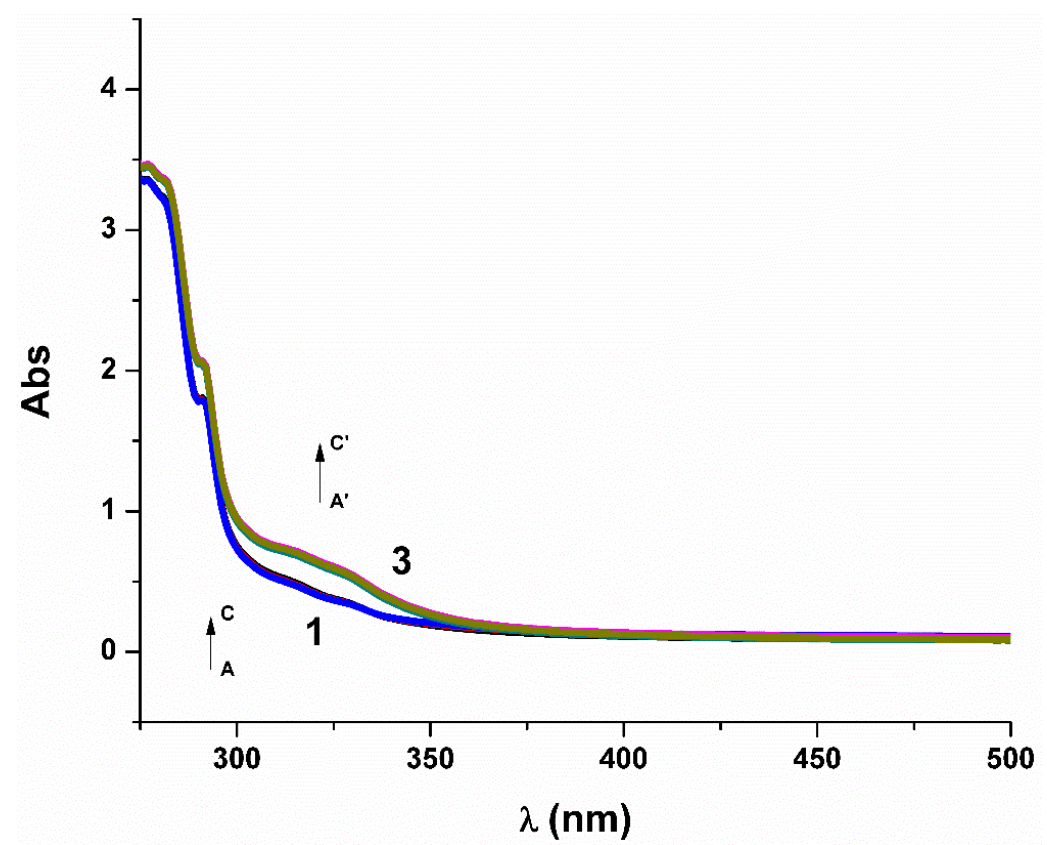

Figure 7. UV-vis spectra of $1 \mathrm{ppm}$ complexes 1 and 3 taken in acetonitrile with the presence of $0.5 \%$ $v / v$ BPS (pH 7.0) at room temperature. 


\subsection{Effect on ROS Level}

Flow cytometry analysis of ROS level was measured by using a fluorescent dihydroethidium (DHE) probe. Complex 2 treated MCF-7 cells indicated the progressive increase in ROS in a dose-dependent manner $(1,5$, and $10 \mu \mathrm{M})$ as shown in Figure 8 . The shift in the peaks towards the right as compared to the control indicates the increment in ROS levels in complex 2 treated MCF-7 cells. The accumulation of ROS is known to induce apoptosis, as confirmed by the results of a recent study [58].

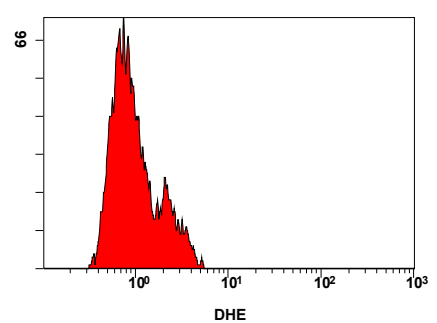

Control

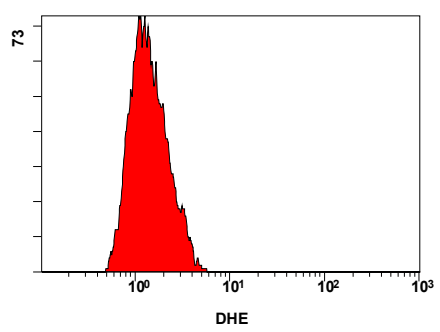

$5 \mu \mathrm{M}$

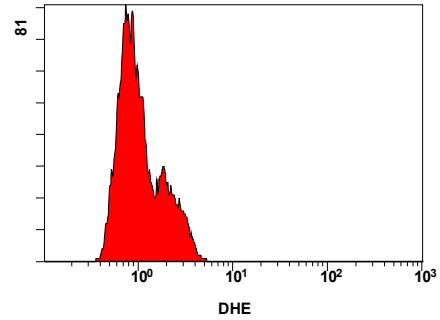

$1 \mu \mathrm{M}$

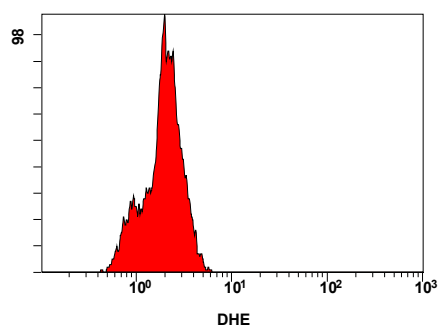

$10 \mu \mathrm{M}$

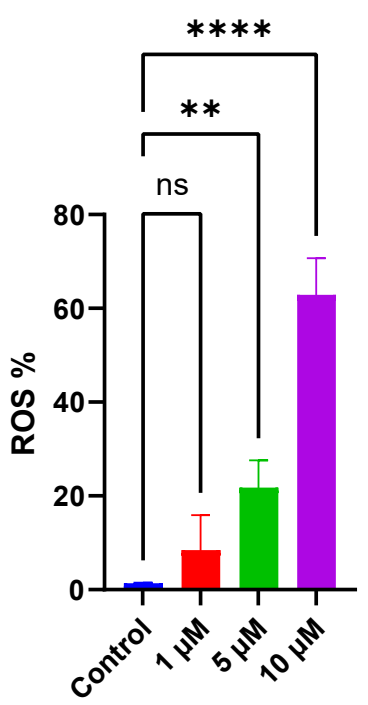

Figure 8. The effect of complex 2 concentrations on ROS levels in MCF-7 cells. The shift of the peaks toward the right shows increasing ROS accumulation in treated cells. The $\left(^{* *}\right)$ and $\left({ }^{* * * *}\right)$ is significant compare to control.

\subsection{Effect on Mitochondrial Membrane Potential}

Apoptosis increases mitochondrial membrane permeability, lowering the transmembrane potential of the mitochondrial membrane. The decreasing mitochondrial membrane potential has been associated with apoptosis and DNA damage induction, indicating that apoptosis is also associated with the mitochondrial pathway. Figure 9 shows how the concentration of complex $2(1,5$, and $10 \mu \mathrm{M})$ decreases the mitochondrial membrane potential. In the control group, membrane potential decrease was observed at $97.3 \%$ in MCF-7 cells, while the highest mitochondrial membrane potential decrease was observed at $86.0 \%$ with $10 \mu \mathrm{M}$ complex 2 . The percentage indicates that the mitochondrial membrane potential decreases with increasing complex 2 concentration $(1,5$, and $10 \mu \mathrm{M})$, indicating mitochondrial depolarization and apoptosis induction in complex 2 treated MCF-7 cells. This manner is consistent with the previous results that showed the increased apoptosis and DNA damage with the decreasing mitochondrial membrane potential in MCF-7 cells at a sub-toxic dose of complex 2 [58]. 


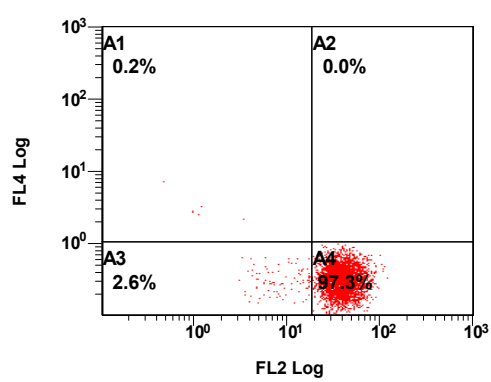

Control

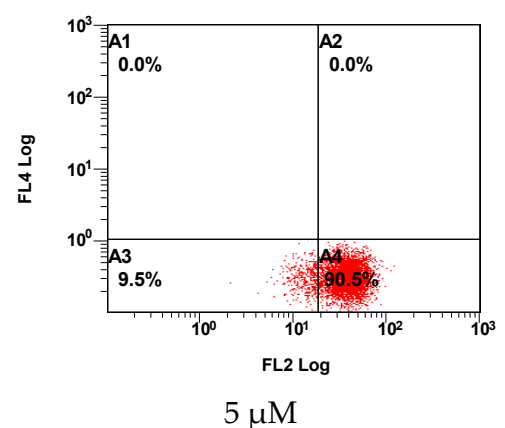

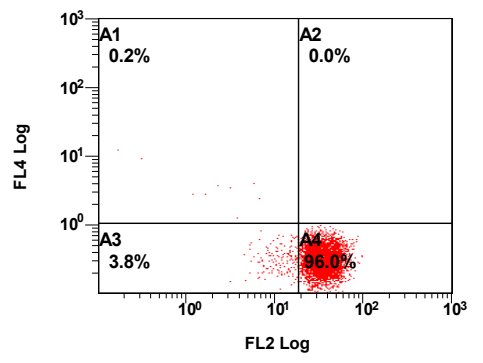

$1 \mu \mathrm{M}$

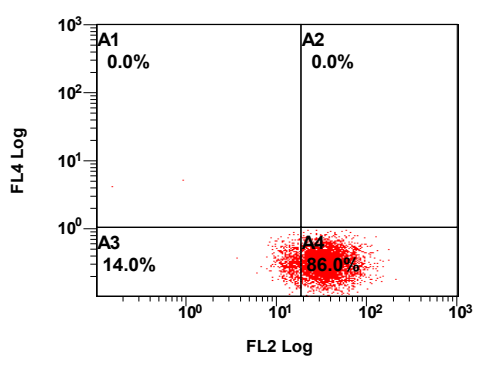

$10 \mu \mathrm{M}$

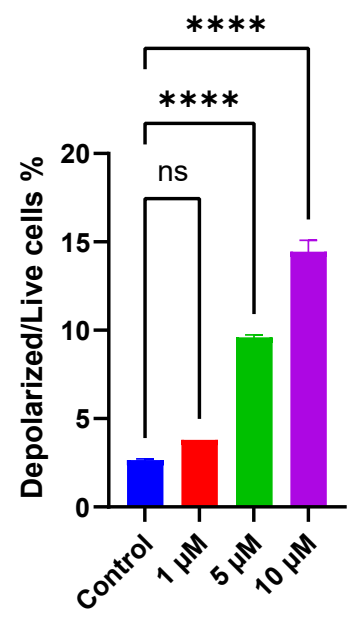

Figure 9. The effect of complex 2 concentrations on mitochondrial membrane potential in MCF-7 cells. The (****) is significant compare to control.

\section{Experiment and Instrumentation}

\subsection{Materials}

Sodium tetrachloridoaurate(III) dihydrate $\left(\mathrm{NaAuCl}_{4} \cdot 2 \mathrm{H}_{2} \mathrm{O}\right), 2,2$-bipyridine-3,3'dicarboxylic acid, and sodium salts of dimethyldithiocarbamate dihydrate, diethyldithiocarbamate, and dibenzyldithiocarbamate were purchased from Sigma Aldrich, Co. (St. Louis, MO, USA). Ethanol, diethyl ether, and dichloromethane were obtained from Fluka AG (St. Gallen, Switzerland). All solvents were of analytical grade and were used without further purification.

\subsection{Instrumentation}

The instruments used to characterize the prepared complexes have been reported in the literature [54].

\subsection{Synthesis of $[\mathrm{Au}($ Bipydc $\left.)) \mathrm{Cl}_{2}\right] \mathrm{Cl}$ (A)}

It was prepared by combining $0.122 \mathrm{~g}(0.5 \mathrm{mmol}) 2,2^{\prime}$-bipyridine-3,3'-dicarboxylic acid in $10 \mathrm{~mL}$ of ethanol and $0.20 \mathrm{~g}(0.5 \mathrm{mmol}) \mathrm{NaAuCl}_{4} \cdot 2 \mathrm{H}_{2} \mathrm{O}$ in $10 \mathrm{~mL}$ of ethanol. The mixture was stirred for $3 \mathrm{~h}$ at room temperature and then filtered. The yellow product was washed twice with ethanol $(5 \mathrm{~mL})$ and three times with diethyl ether $(10 \mathrm{~mL})$, then dried in the dark and stored in a fridge. Yield $=0.212 \mathrm{~g}, 77.6 \%$. Analysis $\left(\mathrm{C}_{12} \mathrm{H}_{8} \mathrm{AuCl}_{3} \mathrm{~N}_{2} \mathrm{O}_{4}, 547.52\right)$ : Calcd. C 26.32, H 1.47, N 5.11; found C 25.98, H 1.53, N 5.54.

\subsection{Synthesis of Complexes 1-3}

In the first step, $0.122 \mathrm{~g}(0.5 \mathrm{mmol}) 2,2^{\prime}$-bipyridine-3,3'-dicarboxylic acid in $10 \mathrm{~mL}$ of ethanol was added to $0.200 \mathrm{~g}(0.5 \mathrm{mmol}) \mathrm{Na}\left[\mathrm{AuCl}_{4}\right] \cdot 2 \mathrm{H}_{2} \mathrm{O}$ in $10 \mathrm{~mL}$ of ethanol, and the mixture was stirred for $3 \mathrm{~h}$, generating a yellow product. In the second step, $0.5 \mathrm{mmol}$ of the respective sodium dithiocarbamate in $5 \mathrm{~mL}$ of ethanol was added dropwise to the above mixture. The mixture was stirred for an additional $10 \mathrm{~min}$. For complexes 1 and 2, yellow precipitates were obtained, while in the case of 3 , it was an orange color. The products were collected by filtration, washed with distilled water $(3 \times 10 \mathrm{~mL})$, and dried under vacuum. Yield: $0.215 \mathrm{~g}$, 68\% for $1 ; 0.245 \mathrm{~g}, 74.2 \%$ for $2 ; 0.278 \mathrm{~g}, 71 \%$ for 3 . 


\subsection{Analysis}

$\left(\mathrm{C}_{15} \mathrm{H}_{14} \mathrm{AuCl}_{2} \mathrm{~N}_{3} \mathrm{O}_{4} \mathrm{~S}_{2}, 632.30\right)$ : Calcd. C 28.49, H 2.23, N 6.64, S 10.14; found C 28.21, $\mathrm{H} 2.36, \mathrm{~N} 6.54, \mathrm{~S} 9.98$.

$\left(\mathrm{C}_{17} \mathrm{H}_{18} \mathrm{AuCl}_{2} \mathrm{~N}_{3} \mathrm{O}_{4} \mathrm{~S}_{2}, 660.35\right)$ : Calcd. C $30.92, \mathrm{H}$ 2.74, N 6.36, S 9.71; found C 30.89, $\mathrm{H}$ 2.80, N 6.54, S 10.01 .

$\left(\mathrm{C}_{27} \mathrm{H}_{22} \mathrm{AuCl}_{2} \mathrm{~N}_{3} \mathrm{O}_{4} \mathrm{~S}_{2}, 784.49\right)$ : Calcd. C 41.33, H 2.82, N 5.35, S 8.17; found C 40.99, H 2.74, N 5.45, S 8.31.

\subsection{In Vitro Cytotoxicity Assay}

To assess the cytotoxicity and determine the effective dose, $\mathrm{IC}_{50}$, the MTT assay was used. The human cancer cell lines A549 (lung cancer), HeLa (cervical), MDA-MB-231 (breast), and MCF-7 (breast) were cultured in a 96-well plate at $5 \times 10^{4}$ cells/well in quadruplicate in $150 \mu \mathrm{L}$ DMEM for $24 \mathrm{~h}$. They were treated with cisplatin and complexes (A, 1, 2, and 3) at concentrations of $0.3,1,3,10,30$, and $100 \mu \mathrm{M}$ for $24 \mathrm{~h}$. Then, $15 \mu \mathrm{L}$ of DMEM containing MTT (3-(4,5-dimethylthiazol-2-yl)-2,5-diphenyltetrazolium bromide) $(5 \mathrm{mg} / \mathrm{mL})$ was added to each well and placed in a $\mathrm{CO}_{2}$ incubator at $37^{\circ} \mathrm{C}$ for $3 \mathrm{~h}$. After incubation, a purple-colored formazan was produced and appeared as dark crystals at the bottom of the wells. The culture medium was discarded from each well and replaced with $100 \mu \mathrm{L}$ of isopropanol to dissolve the formazan crystals. The absorbance of the 96 -well plate was taken at $570 \mathrm{~nm}$ with Mithras2LB943 against reagent blank. The $\mathrm{IC}_{50}$ value for each sample was calculated using GraphPad 6.0 and Excel 2019.

\subsection{Apoptosis Analysis for Complex $\mathbf{2}$}

To detect the apoptotic effect of complex 2 on MCF-7 cells, we used the (FITC) Annexin V Apoptosis Detection Kit (BioLegend, San Diego, CA, USA). The cells were seeded in 6-well plates, at $5 \times 10^{4}$ cells per well, and treated with different concentrations of complex $2(0,1$, and $5 \mu \mathrm{M})$ for $24 \mathrm{~h}$. After harvesting the cells, cell suspension was stained with FITC Annexin V/7-AAD according to the manufacture's protocol. Cells treated with a DMSO concentration of less than $0.1 \%(v / v)$ were used as a control. All samples were analyzed using a flow cytometer (Beckman Coulter, FC500, Indianapolis, IN, USA).

\subsection{DNA Damage of Complex 2}

Besides apoptosis, the ability to induce DNA damage upon treatment was investigated. MCF-7 cells were seeded in 6-well plates, at $5 \times 10^{4}$ cells per well, and treated with complex 2 at concentrations of 0,1 , and $5 \mu \mathrm{M}$ for $24 \mathrm{~h}$. Cells treated with a DMSO concentration of less than $0.1 \%(v / v)$ were used as a control. Then, cells were harvested and prepared with the Muse Multi-Color DNA Damage Kit (Merck Millipore, Burlington, MA, USA) according to the manufacturer's protocol. The percentage of DNA damage was assessed using flow cytometry (Beckman Coulter, FC500, Indianapolis, IN, USA).

\subsection{ROS Production of Complex 2}

To estimate the level of ROS, MCF-7 cells were seeded in 6-well plates, at $5 \times 10^{4}$ cells per well, followed by incubation for $24 \mathrm{~h}$ at $5 \% \mathrm{CO}_{2}, 37{ }^{\circ} \mathrm{C}$, and a $95 \%$ humidified environment. Varying concentrations of Complex $2(1,5$, and $10 \mu \mathrm{M})$ were added to each well and incubated for $24 \mathrm{~h}$, with a DMSO concentration of less than $0.1 \%(v / v)$; untreated cells were used as a negative control. After incubation, cells were collected and washed with 1X PBS, following the Muse oxidative stress kit protocol (Merck Millipore, Burlington, MA, USA). Briefly, the washed cells were suspended in $1 \mathrm{X}$ assay buffer and then incubated for $30 \mathrm{~min}$ at $37^{\circ} \mathrm{C}$ after adding the oxidative stress reagent. We estimated the percentage of ROS using flow cytometry (Beckman Coulter, FC500, Indianapolis, IN, USA).

\subsection{Mitochondrial Membrane Potential of Complex 2}

MCF-7 cells were seeded in 6-well plates, at $5 \times 10^{4}$ cells per well, followed by incubation for $24 \mathrm{~h}$ at $5 \% \mathrm{CO}_{2}, 37{ }^{\circ} \mathrm{C}$, and a $95 \%$ humidified environment. Varying 
concentrations of Complex $2(1,5$, and $10 \mu \mathrm{M})$ were added to the each well and incubated for $24 \mathrm{~h}$. Cells treated with a DMSO concentration of less than $0.1 \%(v / v)$ were used as a control. Then, cells were harvested and prepared with the Muse MitoPotential kit (Merck Millipore, Burlington, MA, USA) according to the manufacturer's protocol. Briefly, $95 \mu \mathrm{L}$ of MitoPotential and $5 \mu \mathrm{L}$ of 7 -AAD reagents were added to cells. Then, they were incubated for $20 \mathrm{~min}$ in a $37^{\circ} \mathrm{C} \mathrm{CO}_{2}$ incubator. The percentage of depolarized cells was assessed by flow cytometry (Beckman Coulter, FC500, Indianapolis, IN, USA).

\subsection{Statistical Analysis}

All results are reported as mean values \pm standard deviation. A one-way ANOVA test was used for all comparison results.

\section{Conclusions}

Three new gold(III) complexes (1-3) containing 2,2'-bipyridine-3,3'-dicarboxylic acid and dithiocarbamate ligands have been synthesized and spectroscopically characterized. The spectroscopic data supported the coordination of both ligands to the gold(III) ion. In vitro cytotoxicity assay of the complexes demonstrated that they possess very high activity as compared to cisplatin. The results reveal that the dithiocarbamate group plays a significant role in the cytotoxicity of complexes. The apoptosis analyses revealed that the complexes inhibited proliferation, through the induction of apoptosis. The apoptosis induction also triggered DNA damage, oxidative stress (confirmed by accumulated ROS), and depolarization of the mitochondrial membrane, showing the great potential of tested gold(III) complexes (A, 1-3) for anti-cancer activity. The promising results of this study stress the need for further preclinical evaluation of this series of gold compounds to test their clinical potential.

Author Contributions: All authors are involved in methodology except M.M.-u.M.; investigation, A.A. and M.A.; data curation, H.M.A.S. and W.Q.; writing-original draft, M.M.-u.M.; writingreview and editing, S.A.; project administration, A.A.I.; conceptualization and supervision, A.A.I. All authors have read and agreed to the published version of the manuscript.

Funding: This research and the APC were funded by the Deanship of Scientific Research at King Saud University No. (RG-1441-496).

Institutional Review Board Statement: Not applicable.

Informed Consent Statement: Not applicable.

Data Availability Statement: Not applicable.

Acknowledgments: The authors extend their appreciation to the Deanship of Scientific Research at King Saud University for funding this work through research group No (RG-1441-496).

Conflicts of Interest: There is no conflict of interest.

Sample Availability: Samples of the compounds are not available from authors.

\section{References}

1. Johnstone, T.C.; Suntharalingam, K.; Lippard, S.J. The Next Generation of Platinum Drugs: Targeted Pt(II) Agents, Nanoparticle Delivery, and Pt(IV) Prodrugs. Chem. Rev. 2016, 116, 3436-3486. [CrossRef] [PubMed]

2. Dilruba, S.; Kalayda, G.V. Platinum-based drugs: Past, present and future. Cancer Chemother. Pharmacol. 2016, 77, 1103-1124. [CrossRef] [PubMed]

3. Ahmad, S. Kinetic aspects of platinum anticancer agents. Polyhedron 2017, 138, 109-124. [CrossRef]

4. Wheate, N.J.; Walker, S.; Craig, G.E.; Oun, R. The status of platinum anticancer drugs in the clinic and in clinical trials. Dalton Trans. 2010, 39, 8113-8127. [CrossRef] [PubMed]

5. Bertrand, B.; Williams, M.R.M.; Bochmann, M. Gold(III) Complexes for Antitumor Applications: An Overview. Chem. A Eur. 2018, 24, 11840-11851. [CrossRef]

6. Ott, I. On the medicinal chemistry of gold complexes as anticancer drugs. Coord. Chem. Rev. 2009, 253, 1670-1681. [CrossRef]

7. Zhang, C.; Maddelein, M.L.; Wai-Yin, S.R.; Gornitzka, H.; Cuvillier, O.; Hemmert, C. Pharmacomodulation on Gold-NHC complexes for anticancer applications- is lipophilicity the key point? Eur. J. Med. Chem. 2018, 157, 320-332. [CrossRef] 
8. Gabbiani, C.; Casini, A.; Messori, L. Gold(III) compounds as anticancer drugs. Gold Bull. 2007, 40, 73-81. [CrossRef]

9. Carotti, S.; Guerrib, A.; Mazzei, T.; Messori, L.; Mini, E.; Orioli, P. Gold(III) compounds as potential antitumor agents: Cytotoxicity and DNA binding properties of some selected polyamine-gold(III) complexes. Inorg. Chim. Acta 1998, 281, 90-94. [CrossRef]

10. Messori, L.; Abbate, F.; Marcon, G.; Orioli, P.; Fontani, M.; Mini, E.; Mazzei, T.; Carotti, S.; O'Connell, T.; Zanello, P. Gold(III) complexes as potential antitumor agents: Solution chemistry and cytotoxic properties of some selected gold(III) compounds. $J$. Med. Chem. 2000, 43, 3541-3548. [CrossRef]

11. Marcon, G.; Carotti, S.; Coronnello, M.; Messori, L.; Mini, E.; Orioli, P.; Mazzei, T.; Cinellu, M.A.; Minghetti, G. Gold(III) complexes with bipyridyl ligands: Solution chemistry, cytotoxicity, and DNA binding properties. J. Med. Chem. 2002, 45, 1672-1677. [CrossRef]

12. Casini, A.; Cinellu, M.A.; Minghetti, G.; Gabbiani, C.; Coronnello, M.; Mini, E.; Messori, L. Structural and solution chemistry, antiproliferative effects, and DNA and protein binding properties of a series of dinuclear gold(III) compounds with bipyridyl ligands. J. Med. Chem. 2006, 49, 5524-5531. [CrossRef]

13. Casini, A.; Diawara, M.C.; Scopelliti, R.; Zakeeruddin, S.M.; Grätzel, M.; Dysona, P.J. Synthesis, characterisation and biological properties of gold(III) compounds with modified bipyridine and bipyridylamine ligands. Dalton Trans. 2010, 39, $2239-2245$. [CrossRef] [PubMed]

14. Khan, T.-M.; Gul, N.S.; Lu, X.; Wei, J.-H.; Liu, Y.-C.; Sun, H.; Liang, H.; Orvig, C.; Chena, Z.-F. In vitro and in vivo anti-tumor activity of two gold(III) complexes with isoquinoline derivatives as ligands. Eur. J. Med. Chem. 2019, 163, 333-343. [CrossRef]

15. Martín-Santos, C.; Michelucci, E.; Marzo, T.; Messori, L.; Szumlas, P.; Bednarski, P.J.; Mas-Balleste, R.; Navarro-Ranninger, C.; Cabrera, S.; Alemán, J. Gold(III) complexes with hydroxyquinoline, aminoquinoline and quinoline ligands: Synthesis, cytotoxicity, DNA and protein binding studies. J. Inorg. Biochem. 2015, 153, 339-345. [CrossRef]

16. Altaf, M.; Ahmad, S.; Kawde, A.-N.; Baig, N.; Alawad, A.; Altuwaijri, S.; Helen Stoeckli-Evansf, H.; Isab, A.A. Synthesis, structural characterization, electrochemical behavior and anticancer activity of gold(III) complexes of meso-1,2-di(1-naphthyl)1,2-diaminoethane and tetraphenylporphyrin. New J. Chem. 2016, 40, 8288-8295. [CrossRef]

17. Pantelić, N.; Zmejkovski, B.B.; Kolundžija, B.; Crnogorac, M.Đ.; Vujić, J.M.; Dojčinović, B.; Trifunović, S.R.; Stanojković, T.P.; Sabo, T.J.; Kaluđerović, G.N. In vitro antitumor activity, metal uptake and reactivity with ascorbic acid and BSA of some gold(III) complexes with N, $\mathrm{N}^{\prime}$-ethylenediamine bidentate ester ligands. J. Inorg. Biochem. 2017, 172, 55-66. [CrossRef] [PubMed]

18. Durovic, M.D.; Bugarcic, Z.D.; Van Eldik, R. Stability and reactivity of gold compounds-From fundamental aspects to applications. Coord. Chem. Rev. 2017, 338, 186-206. [CrossRef]

19. Altaf, M.; Casagrande, N.; Mariotto, E.; Baig, N.; Kawde, A.-N.; Corona, G.; Larcher, R.; Borghese, C.; Pavan, C.; Seliman, A.A.; et al. Potent In Vitro and In Vivo Anticancer Activity of New Bipyridine and Bipyrimidine Gold(III) Dithiocarbamate Derivatives. Cancers 2019, 11, 474. [CrossRef]

20. Altaf, M.; Monim-Ul-Mehboob, M.; Kawde, A.-N.; Corona, G.; Larcher, R.; Ogasawara, M.; Casagrande, N.; Celegato, M.; Borghese, C.; Siddik, Z.H.; et al. New bipyridine gold(III) dithiocarbamate-containing complexes exerted a potent anticancer activity against cisplatin-resistant cancer cells independent of p53 status. Oncotarget 2017, 8, 490-505. [CrossRef]

21. Amani, V.; Abedi, A.; Ghabeshi, S.; Khavasi, H.R.; Hosseini, S.M.; Safari, N. Synthesis and characterization of a series of gold(III) complexes with the 4,4'-dimethyl-2,2'-bipyridine ligand: Counter ion influence on the cytotoxicity of gold(III) complexes. Polyhedron 2014, 79, 104-115. [CrossRef]

22. Gabbiani, C.; Casini, A.; Messori, L.; Guerri, A.; Cinellu, M.A.; Minghetti, G.; Corsini, M.; Rosani, C.; Zanello, P.; Arca, M. Structural characterization, solution studies, and DFT calculations on a series of binuclear gold(III) oxo complexes: Relationships to biological properties. Inorg. Chem. 2008, 47, 2368-2379. [CrossRef] [PubMed]

23. Casini, A.; Kelter, G.; Gabbiani, C.; Cinellu, M.A.; Minghetti, G.; Fregona, D.; Fiebig, H.H.; Messori, L. Chemistry, antiproliferative properties, tumor selectivity, and molecular mechanisms of novel gold(III) compounds for cancer treatment: A systematic study. J. Biol. Inorg. Chem. 2009, 14, 1139-1149. [CrossRef] [PubMed]

24. Al-Jaroudi, S.S.; Fettouhi, M.; Wazeer, M.I.M.; Isab, A.A.; Altuwaijri, S. Synthesis, characterization and cytotoxicity of new gold(III) complexes with 1,2-diamino-cyclohexane: Influence of stereochemistry on antitumor activity. Polyhedron 2013, 50, 434-442. [CrossRef]

25. Monim-ul-Mehboob, M.; Altaf, M.; Fettouhi, M.; Isab, A.A.; Wazeer, M.I.M.; Shaikh, N.; Altuwaijri, S. Synthesis, spectroscopic characterization and anti-cancer properties of new gold(III)-alkanediamine complexes against gastric, prostate and ovarian cancer cells; crystal structure of $\left[\mathrm{Au}_{2}(\mathrm{pn})_{2}(\mathrm{Cl})_{2}\right] \mathrm{Cl}_{2} \cdot \mathrm{H}_{2} \mathrm{O}$. Polyhedron 2013, 61, 225-234. [CrossRef]

26. Al-Jaroudi, S.S.; Monim-ul-Mehboob, M.; Altaf, M.; Fettouhi, M.; Wazeer, M.I.M.; Altuwaijri, S.; Isab, A.A. Synthesis, spectroscopic characterization, X-ray structure and electrochemistry of new bis(1,2-diaminocyclohexane)gold(III) chloride compounds and their anticancer activities against PC3 and SGC7901 cancer cell lines. New J. Chem. 2014, 38, 3199-3211. [CrossRef]

27. Al-Jaroudi, S.S.; Monim-ul-Mehboob, M.; Altaf, M.; Al-Saadi, A.A.; Wazeer, M.I.M.; Altuwaijri, S.; Isab, A.A. Synthesis, spectroscopic characterization, electrochemical behavior and computational analysis of mixed diamine ligand gold(III) complexes: Antiproliferative and in vitro cytotoxic evaluations against human cancer cell lines. Biometals 2014, 27, 1115-1136. [CrossRef]

28. Al-Jaroudi, S.S.; Altaf, M.; Al-Saadi, A.A.; Kawde, A.-N.; Altuwaijri, S.; Ahmad, S.; Isab, A.A. Synthesis, characterization and theoretical calculations of (1,2-diaminocyclohexane)(1,3-diaminopropane)gold(III) chloride complexes: In vitro cytotoxic evaluations against human cancer cell lines. Biometals 2015, 28, 827-844. [CrossRef] 
29. Omer, K.H.; Seliman, A.A.; Altaf, M.; Naike, C.; Aldinucci, D.; Altuwaijri, S.; Isab, A.A. Synthesis, characterization and anticancer activity of gold(III) complexes with (1R,2R)-(-)-1,2-diaminocyclohexane. Polyhedron 2015, 102, 773-781. [CrossRef]

30. Ronconi, L.; Giovagnini, L.; Marzano, C.; Bettìo, F.; Graziani, R.; Pilloni, G.; Fregona, D. Gold Dithiocarbamate Derivatives as Potential Antineoplastic Agents: Design, Spectroscopic Properties, and in Vitro Antitumor Activity. Inorg. Chem. 2005, 44, 1867-1881. [CrossRef] [PubMed]

31. Ronconi, L.; Marzano, C.; Zanello, P.; Corsini, M.; Miolo, G.; Maccà, C.; Trevisan, A.; Fregona, D. Gold(III) dithiocarbamato derivatives for the treatment of cancer: Solution chemistry, DNA binding, and hemolytic properties. J. Med. Chem. 2006, 49, 1648-1657. [CrossRef] [PubMed]

32. Milacic, V.; Chen, D.; Ronconi, L.; Landis-Piwowar, K.R.; Fregona, D.; Dou, Q.P. A novel anticancer gold(III) dithiocarbamate compound inhibits the activity of a purified $20 \mathrm{~S}$ proteasome and $26 \mathrm{~S}$ proteasome in human breast cancer cell cultures and xenografts. Cancer Res. 2006, 66, 10478-10486. [CrossRef] [PubMed]

33. Saggioro, D.; Rigobello, M.P.; Paloschi, L.; Folda, A.; Moggach, S.A.; Parsons, S.; Ronconi, L.; Fregona, D.; Bindoli, A. Gold(III)dithiocarbamato complexes induce cancer cell death triggered by thioredoxin redox system inhibition and activation of ERK pathway. Chem. Biol. 2007, 14, 1128-1139. [CrossRef]

34. Cattaruzza, L.; Fregona, D.; Mongiat, M.; Ronconi, L.; Fassina, A.; Colombatti, A.; Aldinucci, D. Antitumor activity of gold(III)dithiocarbamato derivatives on prostate cancer cells and xenografts. Int. J. Cancer. 2011, 128, 206-215. [CrossRef] [PubMed]

35. Marzano, C.; Ronconi, L.; Chiara, F.; Giron, M.C.; Faustinelli, I.; Cristofori, P.; Trevisan, A.; Fregona, D. Gold(III)-dithiocarbamato anticancer agents: Activity, toxicology and histopathological studies in rodents. Int. J. Cancer 2011, 129, 487-496. [CrossRef]

36. Ronconi, L.; Aldinucci, D.; Dou, Q.P.; Fregona, D. Latest insights into the anticancer activity of gold(III)-dithiocarbamato complexes. Anticancer Agents Med. Chem. 2010, 10, 283-292. [CrossRef] [PubMed]

37. Williams, M.R.M.; Bertrand, B.; Hughes, D.L.; Waller, Z.A.E.; Schmidt, C.; Ott, I.; O'Connell, M.; Searcey, M.; Bochmann, M. Cyclometallated $\mathrm{Au}(\mathrm{III})$ dithiocarbamate complexes: Synthesis, anticancer evaluation and mechanistic studies. Metallomics 2018, 10, 1655-1666. [CrossRef] [PubMed]

38. Lum, C.T.; Wong, A.S.-T.; Lin, M.C.M.; Che, C.-M.; Sun, R.W.-Y. A gold(III) porphyrin complex as an anti-cancer candidate to inhibit growth of cancer-stem cells. Chem. Commun. 2013, 49, 4364-4366. [CrossRef]

39. Sun, R.W.-Y.; Che, C.-M. The anti-cancer properties of gold(III) compounds with dianionic porphyrin and tetradentate ligands. Coord. Chem. Rev. 2009, 253, 1682-1691. [CrossRef]

40. Bertrand, B.; Casini, A. A golden future in medicinal inorganic chemistry: The promise of anticancer gold organometallic compounds. Dalton Trans. 2014, 43, 4209-4219. [CrossRef]

41. Messori, L.; Marcon, G.; Cinellu, M.A.; Coronnello, M.; Mini, E.; Gabbiani, C.; Orioli, P. Solution chemistry and cytotoxic properties of novel organogold(III) compounds. Bioorg. Med. Chem. 2004, 12, 6039-6043. [CrossRef]

42. Coronnello, M.; Mini, E.; Caciagli, B.; Cinellu, M.A.; Bindoli, A.; Gabbiani, C.; Messori, L. Mechanisms of Cytotoxicity of Selected Organogold(III) Compounds. J. Med. Chem. 2005, 48, 6761-6765. [CrossRef]

43. Messori, L.; Marcon, G.; Tempi, C.; Orioli, P. Interactions of selected gold(III) complexes with calf thymus DNA. Biochem. Biophys. Res. Commun. 2001, 281, 352-360. [CrossRef]

44. Casini, A.; Hartinger, C.; Gabbiani, C.; Mini, E.; Dyson, P.J.; Bernard, K.; Keppler, B.K.; Messori, L. Gold(III) compounds as anticancer agents: Relevance of gold-protein interactions for their mechanism of action. J. Inorg. Biochem. 2008, 102, 564-575. [CrossRef]

45. Glisic, B.D.; Rychlewska, U.; Djuran, M.I. Reactions and structural characterization of gold(III) complexes with amino acids, peptides and proteins. Dalton Trans. 2012, 41, 6887-6901. [CrossRef]

46. Maiore, L.; Cinellu, A.C.; Nobili, S.; Landini, I.; Mini, E.; Gabbiani, C.; Messori, L. Gold(III) complexes with 2-substituted pyridines as experimental anticancer agents: Solution behavior, reactions with model proteins, antiproliferative properties. J. Inorg. Biochem. 2012, 108, 123-127. [CrossRef]

47. Gamberi, T.; Massai, L.; Magherini, F.; Landini, I.; Tania Fiaschi, T.; Scaletti, F.; Gabbiani, C.; Bianchi, L.; Bini, L.; Nobili, S.; et al. Proteomic analysis of A2780/S ovarian cancer cell response to the cytotoxic organogold(III) compound Aubipyc. J. Proteom. 2014, 103, 103-120. [CrossRef]

48. Barnard, P.J.; Berners-Price, S.J. Targeting the mitochondrial cell death pathway with gold compounds. Coord. Chem. Rev. 2007, 251, 1889-1902. [CrossRef]

49. Bindoli, A.; Rigobello, M.P.; Scutari, G.; Gabbiani, C.; Casini, A.; Messori, L. Thioredoxin reductase: A target for gold compounds acting as potential anticancer drugs. Coord. Chem. Rev. 2009, 253, 1692-1707. [CrossRef]

50. Milacic, V.; Dou, Q.P. The tumor proteasome as a novel target for gold(III) complexes: Implications for breast cancer therapy. Coord. Chem. Rev. 2009, 253, 1649-1660. [CrossRef] [PubMed]

51. Sengul, A. An Atropisomeric Chiral 2,2'-bipyridyl-3,3'-dicarboxylic Acid and Corresponding Platinum(II) Complex. Turk. J. Chem. 2004, 28, 703-713.

52. Yoo, J.; Kim, J.-H.; Sohn, Y.S.; Do, Y. Platinum (II) complexes of 3,3'-disubstituted-2,2'-bipyridines. Synthesis, structures, cytotoxic effect and unusual solvolysis in DMSO. Inorg. Chim. Acta 1997, 263, 53-60. [CrossRef]

53. Zhao, B.-Z.; Hao, X.-R.; Han, Z.-G.; Fu, Q.; Chen, Y.-G. A novel copper(II) coordination polymer with 2,2'-bipyridyl-3,3'dicarboxylic acid. Acta Cryst. 2005, C61, m48-m50. 
54. Al-Jaroudi, S.S.; Altaf, M.; Seliman, A.A.; Yadav, S.; Arjmand, F.; Alhoshani, A.; Korashy, H.M.; Ahmad, S.; Isab, A.A. Synthesis, characterization, in vitro cytotoxicity and DNA interaction study of phosphanegold(I) complexes with dithiocarbamate ligands. Inorg. Chim. Acta. 2017, 464, 37-48. [CrossRef]

55. Alhmoud, J.F.; John, F.; Woolley, J.F.; Al Moustafa, A.-E.; Malki, M.I. DNA Damage/Repair Management in Cancers. Cancers 2020, 12, 1050. [CrossRef] [PubMed]

56. Bartek, J. DNA damage response, genetic instability and cancer: From mechanistic insights to personalized treatment. Mol. Oncol. 2011, 5, 303-307. [CrossRef]

57. Skulachev, V.P. Bioenergetic aspects of apoptosis, necrosis and mitoptosis. Apoptosis 2006, 11, 473-485. [CrossRef]

58. Czarnomysy, R.; Radomska, D.; Muszyńska, A.; Hermanowicz, J.M.; Prokop, I.; Bielawska, A.; Bielawski, K. Evaluation of the Anticancer Activities of Novel Transition Metal Complexes with Berenil and Nitroimidazole. Molecules 2020, 25, 2860. [CrossRef] 